\title{
Exploring hydrocarbonoclastic bacterial communities in the estuarine surface microlayer
}

\author{
Francisco J. R. C. Coelho ${ }^{1}$, Sara Sousa ${ }^{2}$, Luísa Santos ${ }^{1}$, \\ Ana L. Santos ${ }^{1}$ Adelaide Almeida ${ }^{1}$, Newton C. M. Gomes ${ }^{1}$, Ângela Cunha ${ }^{1, *}$ \\ ${ }^{1}$ Department of Biology \& CESAM, University of Aveiro, Campus de Santiago, 3810-193 Aveiro, Portugal \\ ${ }^{2}$ Department of Biology, University of Aveiro, Campus de Santiago, 3810-193 Aveiro, Portugal
}

\begin{abstract}
Bacteria that degrade polycyclic aromatic hydrocarbons (PAHs) in the estuarine surface microlayer (SML) of the Ria de Aveiro, Portugal — which is chronically polluted with oil hydrocarbons $(\mathrm{OH})$ - were isolated and characterized; Pseudomonas was dominant among the PAH-degrading bacteria. Screening for PAH dioxygenase genes detected almost identical nahAc genes (encoding the alpha subunits of naphthalene dioxygenase) in 2 phylogenetically distinct isolates: Pseudomonas sp. and an unknown species of the family Enterobacteriaceae; this suggested that horizontal transfer of nah genes might be involved in PAH degradation in the SML. We also investigated the effect of PAH contamination on the spatial variability of the bacterioneuston along a gradient of pollution in the estuarine system of the Ria de Aveiro. Culture-independent techniques-fluorescence in situ hybridization (FISH) and denaturing-gradient gel electrophoresis (DGGE) - revealed a similar structure among the bacterioneuston communities along the estuary. In contrast, we detected differences in the relative abundance and diversity of organisms of the Gammaproteobacteria, including those of the genus Pseudomonas (which belongs to the Gammaproteobacteria). This is the first insight into the hydrocarbonoclastic bacterial communities in the SML of an estuarine area polluted with hydrocarbons. Our findings highlight the importance of SML-adapted hydrocarbonoclastic bacterioneuston as a potential source of new PAH-degrading bacteria (including new pseudomonads) with potential use in the bioremediation of hydrocarbon-polluted ecosystems.
\end{abstract}

KEY WORDS: Sea surface microlayer $\cdot$ Bacterioneuston $\cdot$ Polycyclic aromatic hydrocarbons $\cdot$ PAH degradation

\section{INTRODUCTION}

The surface microlayer (SML) is the interface between the atmosphere and the hydrosphere. This layer is roughly defined as the uppermost millimetre of the water column, and is characterized as a unique environment with distinct chemical and physical processes when compared with the underlying water (UW) (Liss \& Duce 1997, Cunliffe \& Murrell 2009, Cunliffe et al. 2011).

The formation of the SML results from the accumulation of particles at the air-water interface, establishing a film that extends into the UW (Cunliffe et al. 2011). Recently, the classical model of the SML as a stratified structure with an upper lipid and a lower protein-poly- saccharide layer (Hardy 1982) has been reviewed. Wurl \& Holmes (2008) reported that the enrichment of transparent exopolymer particles (TEPs) in the SML at several locations around Singapore appears to support the model of the SML first advanced by Sieburth (1983), i.e. a hydrated gelatinous film (Sieburth 1983, Wurl \& Holmes 2008, Cunliffe \& Murrell 2009, Cunliffe et al. 2011).

The organisms within the SML are known collectively as neuston; the bacterial fraction of the neuston is the bacterioneuston (Franklin et al. 2005). The importance of the SML in the control of environmental processes, and in the exchange of chemicals between the water and the atmosphere (Wurl \& Obbard 2004, Obernosterer et al. 2005, Cunliffe \& Murrell 2009), has 
raised interest in the effects of the activities of the bacterioneuston in this ecosystem. Cunliffe et al. (2008) found evidence that the diversity of functional genes encoding subunits of methane monoxygenase (mmox) and carbon monoxide dehydrogenase (coxL) is different in the SML when compared with the UW (Cunliffe et al. 2008). There is an emerging consensus that the SML harbours microbial communities distinct from those in the UW (for a full review see Cunliffe et al. 2011); however, there is still a lack of knowledge on both the structure and function of the SML community. For example, due to the chemical nature of the SML, natural and anthropogenic aromatic compounds-e.g. polycyclic aromatic hydrocarbons (PAHs) - can be concentrated up to $500 \times$ in this layer in relation to the rest of the water column (Wurl \& Obbard 2004). High concentrations of PAHs have been found in the SML at locations chronically polluted with oil hydrocarbons $(\mathrm{OH})$, such as shipping harbours (Cincinelli et al. 2001, Wurl \& Obbard 2004). However, so far, no studies have exploited the potential of microorganisms in the SML to degrade PAHs, or have investigated the effect of PAHs on the bacterioneuston. It is reasonable to hypothesize that the increased levels of PAHs in the SML may stimulate the development of hydrocarbonoclastic bacterial populations in this layer. However, studies on the affect of $\mathrm{PAH}$ pollution on bacterioneuston are scarce, and none has specifically addressed the hydrocarbonoclastic bacterial populations of the SML.

In order to obtain more information about the bacterioneuston, and the potential of these organisms to degrade PAHs, we: (1) isolated and identified representatives of the hydrocarbonoclastic population in the SML, and (2) screened the isolates for genes encoding enzymes involved in the degradation of PAHs. We also evaluated the effect of $\mathrm{OH}$ pollution on the spatial variability of the bacterioneuston along a gradient of contamination in the estuarine system of the Ria de Aveiro in Portugal.

\section{MATERIALS AND METHODS}

Study site and sampling. Ria de Aveiro is a branched estuarine ecosystem, also described as a coastal lagoon, located in the northwest coast of Portugal. Samples for the selective isolation of hydrocarbonoclastic bacterioneuston were obtained from the SML in the middle section of the estuary, near a shipping harbour.

In order to characterize the spatial variation of the bacterioneuston, 5 collecting points were chosen for sampling. Extending from the outer segment of the lagoon to the inner section of Canal de Ílhavo, the sites were designated: $\mathrm{S} 1\left(40^{\circ} 40^{\prime} 01^{\prime \prime} \mathrm{N}, 08^{\circ} 49^{\prime} 24^{\prime \prime} \mathrm{W}\right)$ in the outer section, $\mathrm{S} 2\left(40^{\circ} 3929 \mathrm{~N}, 08^{\circ} 4212 \mathrm{~W}\right)$ and S3 $\left(40^{\circ} 38^{\prime} 20^{\prime \prime} \mathrm{N}, 08^{\circ} 41^{\prime} 32^{\prime \prime} \mathrm{W}\right)$ in the middle section (near the shipping harbour), and S4 $\left(40^{\circ} 37^{\prime} 21^{\prime \prime} \mathrm{N}\right.$, $\left.08^{\circ} 41^{\prime} 01^{\prime \prime} \mathrm{W}\right)$ and S5 (40 35'41" N, 08 41'21"W) in the inner section of the Canal de Ílhavo (Fig. 1).

Samples were collected from the SML with plexiglass and glass plates. Both plates were $0.25 \mathrm{~m}$ wide, $0.35 \mathrm{~m}$ long, and $4 \mathrm{~mm}$ thick. Prior to sample collection, the plates were rinsed with ethanol and sterile distilled water. The plates were introduced vertically through the SML and withdrawn in the same position. Excess water was allowed to drain for about $5 \mathrm{~s}$. Approximately $5 \mathrm{ml}$ of water were collected each time the plates were introduced into the SML. The water adher-

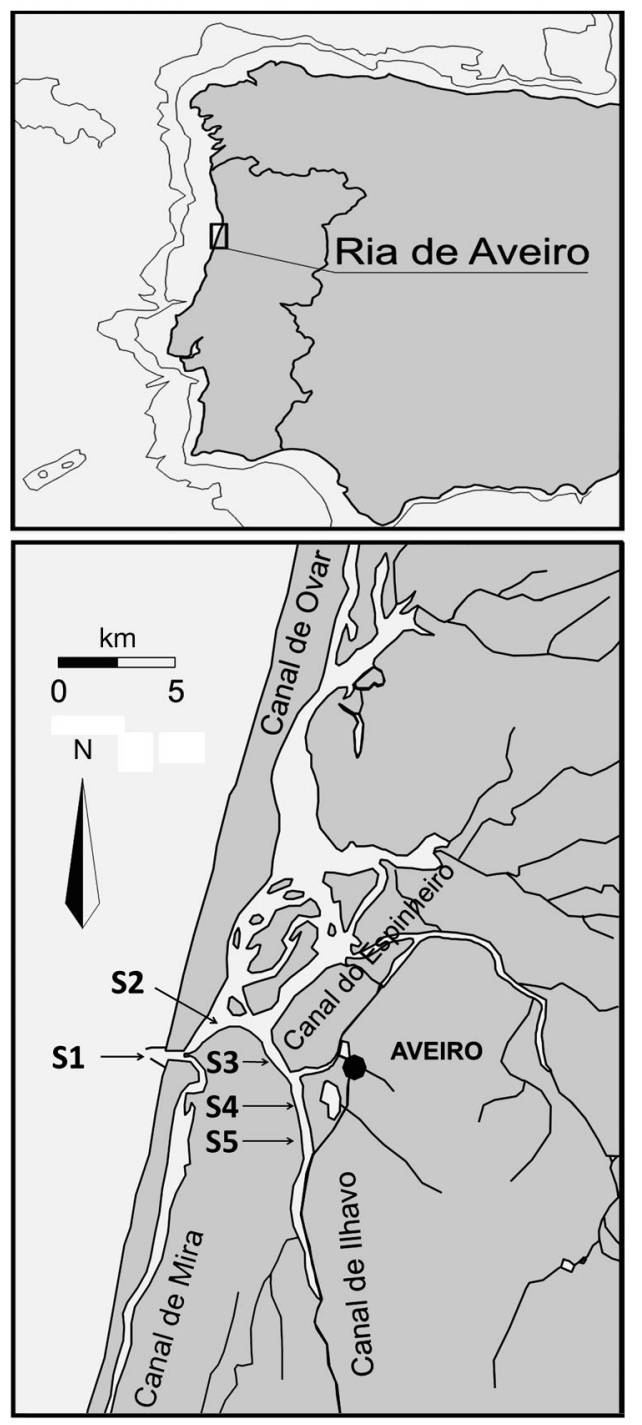

Fig. 1. Ria de Aveiro (Portugal). Sampling sites are indicated with arrows: Stn S1 in the Canal de Navegação, Stns S2 and S3 near the harbour facilities, and Stns S4 and S5 in the Canal de Ílhavo 
ing to the plate was subsequently removed from both sides of the plate with a wiper blade system (Harvey \& Burzell 1972). The estimated thickness of the collected SML, determined from the volume of collected sample and the area of both sides of the plate, was approximately $60 \mu \mathrm{m}$, which is in the range reported by Harvey \& Burzell (1972) for glass plate samplers.

Salinity was determined immediately after the sampling with a WTW (Wissenschaftlich Technische Werkstätten) Cond330i/SET.

Quantification of PAHs was performed by gas chromatography-mass spectrometry (gas chromatograph Varian CP-3800 with split/splitless injection and mass spectrometry detector-Ion Trap Saturn 2200) with detection limits between 20 and $40 \mathrm{ng} \mathrm{l}^{-1}$. The result was calculated as the average of 2 sub-samples and expressed in $\mathrm{ng} \mathrm{l}^{-1}$.

Enrichment and isolation of PAH-degrading bacteria. $\mathrm{A} \mathrm{PAH,} \mathrm{2-methylnaphthalene,} \mathrm{was} \mathrm{used} \mathrm{as} \mathrm{the} \mathrm{sole}$ source of carbon and energy for the enrichment and isolation of PAH-degrading bacteria in a liquid mineral medium (MM). Selective plates were prepared by adding $2 \%$ (wt/vol) agarose to MM. The 2-methylnaphthalene (Fluka) was added by spreading ethanol solutions $\left(50 \mathrm{mg} \mathrm{ml}^{-1}\right)$ onto the surface of the solid medium. Inoculation was carried out only when the solvent had evaporated fully, producing a film of PAH on the surface of the medium (Ma et al. 2006).

Bacterioneuston samples for enrichment cultures were collected near the shipping harbour. A volume of $200 \mathrm{ml}$ of SML sample was added to $800 \mathrm{ml}$ of sterile MM with $200 \mathrm{mg}$ of 2-methylnaphthalene (Fluka) in a 11 sterilized Erlenmeyer flask. The liquid cultures were incubated at room temperature for $2 \mathrm{wk}$, in the absence of light, on a rotary shaker $(90 \mathrm{rpm})$. After the enrichment, $20 \mathrm{ml}$ of culture were transferred to fresh medium and incubated for the same period of time. After 2 similar subcultures, a serial dilution of the culture was spread onto the MM selective plates. These cultures were incubated at $25^{\circ} \mathrm{C}$ for up to $14 \mathrm{~d}$, protected from light. Individual isolated colonies were further purified by re-streaking onto new MM selective plates. Control plates without 2-methylnaphthalene were also incubated.

Extraction of DNA. Genomic DNA was extracted from all the strains recovered from the isolation procedure, as previously described by Henriques et al. (2004). Environmental samples were filtered (pore size: $0.2 \mu \mathrm{m}$; Poretics Products). Total DNA was extracted in 3 replicates and purified using the Genomic DNA Purification Kit (MBI Fermentas) (Henriques et al. 2004).

Molecular characterization and identification of the PAH-degrading bacterial isolates. For molecular typing of the isolates, a repetitive-sequence PCR using a
BOX A1R primer (BOX-PCR fingerprinting) was followed (Rademaker et al. 1998). BOX-PCR profiles were visualized after separation of PCR amplicons by electrophoresis in $2 \%$ agarose gel using $1 \times$ TAE (Trisacetate-EDTA) at $100 \mathrm{~V}$ for $3 \mathrm{~h}$. The gels were stained with ethidium bromide and digitalized in a Molecular Imager FXTM system (Bio-Rad Laboratories). The band positions were normalized with the GeneRuler ${ }^{\mathrm{TM}}$ $1 \mathrm{~kb}$ Plus DNA ladder (75-20000 bp) and analysed with GelCompar I software (Applied Maths) using the pairwise Pearson's product-moment correlation coefficient (r-value). Cluster analysis of the similarity matrices was performed by the unweighted pair-group method (UPGMA) using arithmetic averages.

For isolates displaying distinct BOX-PCR profiles, the 16S rRNA gene was amplified by PCR using the universal bacterial primers U27 and 1492R (Weisburg et al. 1991). PCR products from the amplified $16 \mathrm{~S}$ rRNA were used as templates in the sequencing reactionswhich were carried out using an ABI PRISM BigDye_Terminator Cycle Sequencing Ready Reaction Kit (PE Applied Biosystems). Sequences were subjected to BLAST (Basic Local Alignment Search Tool) analysis.

These isolates were also screened for the Pseudomonas-specific gacA gene using primers GACA-1F and GACA-2 (De Souza et al. 2003). All PCR reagents were purchased from MBI Fermentas unless otherwise indicated.

Detection of the dioxygenase gene. PCR was used for detecting genes that encode enzymes involved in the aerobic degradation of PAHs in the isolated strains. Primers specific for the alpha subunit of the PAH-ring hydroxylating dioxygenases, common to Gram-negative PAH degraders (PAH-RHD $\alpha$ GNF and PAH-RHD $\alpha$ GNR primers), were used to obtain amplicons of ca. 306 bp (Cébron et al. 2008). The PCR products were used as templates in the sequencing reactions. Sequencing was carried out as described in the previous section, and a comparison was made with sequences available in the GenBank database by using the BLAST service to determine their closest relative. All PCR reagents were purchased from MBI Fermentas unless otherwise indicated.

Microbial community structure. Denaturing-gradient gel electrophoresis (DGGE): DGGE was performed on the Pseudomonas-specific gacA gene sequence amplified from bacterial isolates and from environmental samples. This technique was also applied to the 16S rRNA gene sequence amplified from environmental samples.

A nested PCR approach was use to amplify the 16S rRNA gene fragments for DGGE analyses. For the first PCR, the universal bacterial primers U27 and 1492R were used to amplify ca. $1450 \mathrm{bp}$ of the $16 \mathrm{~S}$ rRNA gene 
(Weisburg et al. 1991). The amount of template DNA used per reaction was ca. 10 ng. For the second PCR, $1 \mu \mathrm{l}$ of the product of the first PCR was used as template with bacterial DGGE primers 968F-GC and 1401R (ca. 433 bp) (Nubel et al. 1996).

A nested-PCR approach was also applied to the amplification of Pseudomonas-specific gacA gene fragments for DGGE analysis (Costa et al. 2007). For the first PCR, primers GACA-1F and GACA-2 were used to amplify ca. 425 bp of the gacA gene (De Souza et al. 2003). The amount of template DNA used per reaction was ca. $10 \mathrm{ng}$. An aliquot of $1 \mu \mathrm{l}$ of the product of the first PCR was used as the template for a second PCR with primers gacA1F-GC and gacA2R (Costa et al. 2007). All PCR reagents were purchased from MBI Fermentas unless otherwise indicated.

DGGE analysis was performed with a CBS-DGGE 2401 system (CBS Scientific). The GC-clamped amplicons were applied to a double-gradient polyacrylamide gel containing 6 to $9 \%$ acrylamide (Rotiphorese) with a gradient of 30 to $58 \%$ of denaturant. The run was performed in Tris-acetate-EDTA buffer $(0.5 \mathrm{M}$ Tris-Base, Sigma, 0.05 M EDTA, Sigma; $0.1 \mathrm{M}$ $\mathrm{CH} 3 \mathrm{CO} 2 \mathrm{Na}$, Sigma, $\mathrm{pH} 8.0$ ) at $60^{\circ} \mathrm{C}$ at a constant voltage of $220 \mathrm{~V}$ for $16 \mathrm{~h}$. The DGGE gels were silver stained (Heuer et al. 2001).

The Shannon index of diversity $(\mathrm{H})$ was use to compare the complexity of the DGGE profiles. The band position and relative intensity (abundance) of each lane (community) were used as parameters to indicate categories (Costa et al. 2006). Parametric analysis of variance (ANOVA) was applied to assess significant differences between samples, provided that data were normally distributed.

Fluorescence in situ hybridization (FISH): The relative abundance of members of the domain Bacteria and the Gammaproteobacteria in the SML was assessed by FISH (Pernthaler et al. 2001) using Cy3-labeled oligonucleotide probes (MWG Biotech). Triplicate samples $(1 \mathrm{ml})$ were filtered through polycarbonate filters (pore size: $0.2 \mu \mathrm{m}$; GE Osmonics), fixed with $4 \%$ paraformaldehyde for $30 \mathrm{~min}$ and rinsed with $1 \times$ PBS and MilliQ water. The filters were stored at room temperature until hybridization. The probes used in this study were EUB338 for the domain Bacteria (Amann et al. 1990) and EUB338-II and EUB338-III to cover the phyla Planctomycetes and Verrucomicrobia (Daims et al. 1999). For the Gammaproteobacteria we used the probes GAM42a (Manz et al. 1992) and an unlabelled competitor probe specific for the Betaproteobacteria. A non-binding probe was also used as a control for nonspecific binding (Karner \& Fuhrman 1997). Samples were examined with a Leitz Laborlux K microscope equipped with the appropriate filter sets for fluorescence from 4,6-diamidino-2-phenylindole (DAPI) and
CY3. At least 10 fields were counted per replicate of sample. In addition to the relative abundance of organisms of the domain Bacteria and of the Gammaproteobacteria, it was also possible to obtain a measure of total microorganisms with the DAPI counts. All reagents were purchased from Fluka, except when otherwise indicated.

Total microorganisms (DAPI counts) were tested for normality (Kolmogorov-Smirnov test) before the comparison of means. Parametric ANOVA was performed, provided that data were normally distributed.

\section{RESULTS AND DISCUSSION}

\section{Physical and chemical parameters}

Salinity in the analysed SML samples ranged between $31.4 \%$ (Stn S5) and 36.0\% (Stn S1). Salinity is an important factor that influences the structure and composition of prokaryotic assemblages in estuarine environments (Bouvier \& del Giorgio 2002, Henriques et al. 2004). However, in this study, the variation of salinity along the estuarine profile was very small, and thus does not seem to influence the distribution of bacterial communities.

The PAH analyses revealed that the composition and concentration of PAHs varied along the estuary (Table 1). Concentrations ranged from below the limit of detection of the method to $14 \pm 5 \mathrm{ng} \mathrm{l}^{-1}$ of naphthalene. Stn S1 showed the lowest concentration of PAH (anthracene: $7.3 \pm 0.2 \mathrm{ng} \mathrm{l}^{-1}$ ). In Stns S2 and S3, located near the shipping harbour, naphthalene reached the highest concentrations (S2: $14 \pm 5 \mathrm{ng} \mathrm{l}^{-1}$; S3: $9.4 \pm$ $1.5 \mathrm{ng} \mathrm{l}^{-1}$ ). Naphthalene is the simplest of the oil PAH compounds; it is the most easily degradable and is highly volatile (Sporstol et al. 1983). The 3-ring $\mathrm{PAH}$ compounds anthracene $\left(6.9 \pm 0.2 \mathrm{ng} \mathrm{l}^{-1}\right)$ and phenanthrene $\left(8.1 \pm 1.7 \mathrm{ng} \mathrm{l}^{-1}\right)$ were detected at the Stns S2 and S3, respectively. At Stn S4, fluorene $(9.4 \pm 1.5 \mathrm{ng}$ $\mathrm{l}^{-1}$ ) was the only PAH detected. Stn S5 showed the largest spectrum of PAH compounds (phenanthrene $5.2 \pm 0.1 \mathrm{ng} \mathrm{l} \mathrm{l}^{-1}$, fluoranthrene $8.5 \pm 1.1 \mathrm{ng} \mathrm{l^{-1 }}$, benzo[a]anthracene $5.1 \pm 0.8 \mathrm{ng} \mathrm{l}^{-1}$ and benzo[k]fluoranthene $8.1 \pm 0.6 \mathrm{ng} \mathrm{l}^{-1}$ ).

\section{PAH-degrading isolates: characterization of isolates}

To isolate organisms from hydrocarbonoclastic bacterioneuston populations, in the first phase of this study, our sampling efforts were focused on the region of the Ria de Aveiro near the harbour facilities (see Fig. 1, Stns S2 and S3). This area showed the highest levels of contamination by low-molecular-weight 
Table 1. Concentrations of individual polycyclic aromatic hydrocarbons (PAHs) in the sea surface microlayer at Stns S1, S2, S3, S4 and S5. LD = limit of detection, $\mathrm{BDL}=$ below limit of quantification. Values are means $\pm \mathrm{SD}$

\begin{tabular}{|c|c|c|c|c|c|c|}
\hline \multirow{2}{*}{ PAH } & \multirow[b]{2}{*}{ LD } & \multicolumn{5}{|c|}{ - PAH concentrations $\left(\mathrm{ng} \mathrm{l}^{-1}\right)$ at site } \\
\hline & & S1 & S2 & S3 & S4 & S5 \\
\hline Naphthalene & 8.8 & BDL & $14 \pm 5$ & $9.4 \pm 1.5$ & BDL & BDL \\
\hline Acenaphthylene & 5.0 & BDL & BDL & BDL & BDL & BDL \\
\hline Acenaphthene & 1.7 & BDL & BDL & BDL & BDL & BDL \\
\hline Fluorene & 4.1 & BDL & BDL & BDL & $9.4 \pm 1.5$ & BDL \\
\hline Phenanthrene & 1.9 & BDL & BDL & $8.1 \pm 1.7$ & BDL & $5.2 \pm 0.1$ \\
\hline Anthracene & 6.2 & $7.3 \pm 0.2$ & $6.9 \pm 0.2$ & BDL & BDL & BDL \\
\hline Fluoranthrene & 5.7 & BDL & BDL & BDL & BDL & $8.5 \pm 1.1$ \\
\hline Pyrene & 3.9 & BDL & BDL & BDL & BDL & BDL \\
\hline Chrysene & 7.5 & BDL & BDL & BDL & BDL & BDL \\
\hline Benz[a]anthracene & 3.7 & BDL & BDL & BDL & BDL & $5.1 \pm 0.8$ \\
\hline Benzo[k]fluoranthene & 8.0 & BDL & BDL & BDL & BDL & $8.1 \pm 0.6$ \\
\hline Benzo[b]fluoranthene & 9.5 & BDL & BDL & BDL & BDL & BDL \\
\hline Benzo[a]pyrene & 5.2 & BDL & BDL & BDL & BDL & BDL \\
\hline Indeno[1.2.3-cd]pyrene & 28 & BDL & BDL & BDL & BDL & BDL \\
\hline Dibenzo[a.h]anthracene & 38 & BDL & BDL & BDL & BDL & BDL \\
\hline Benzo(ghi)perylene & 33 & BDL & BDL & BDL & BDL & BDL \\
\hline
\end{tabular}

range of valuable compounds with industrial uses (Wackett 2003). These abilities, together with enhanced stress resistance, amenability to genetic manipulation and suitability as a host for heterologous expression, makes strains of Pseudomonas particulary useful for biotechnological applications (Puchałka et al. 2008).

As well as contamination with PAHs, the estuarine system of the Ria de Aveiro is also subject to chronic contamination with domestic sewage (Cunha et al. 2000). This might explain the large number of isolates related to the family Enterobacteriaceae, such as Klebsiella and Serratia. Nonetheless, the catabolic capacity of Klebsiella strains to degrade hydrocarbons, including PAHs, has been previously described. A recent study suggested that Klebsiella can be an important

PAHs. These PAHs constitute a significant fraction of crude oil and petroleum products and are often used as indicators of recent or chronic contamination with petroleum hydrocarbons (Sporstol et al. 1983).

The PAH 2-methylnaphthalene, a common constituent of crude oil and fossil fuels, was used in this study as the sole source of carbon and energy for the enrichment and isolation of strains of the hydrocarbonoclastic bacterioneuston (Kasai et al. 2002). The isolation procedure recovered 42 bacterial isolates that were able to use 2-methylnaphthalene as the sole source of carbon. Genotypic diversity of the isolates, assessed by the whole-genome BOX-PCR fingerprint method (Rademaker et al. 1998), assigned the isolates to 29 different genotypes. The $16 \mathrm{~S}$ gene sequence analysis showed that all hydrocarbonoclastic isolates were Gram-negative and had high homology with 6 different taxa: Pseudomonas, Klebsiella, Serratia, Acinetobacter, Rhizobium and Vibrio (Table 2).

Pseudomonas and Klebsiella were preponderant, accounting to 34.5 and $31.0 \%$, respectively, of the total representative isolates $(10$ isolates were assigned to the genus Pseudomonas and 9 to Klebsiella). These results point to a high genotypic diversity in the populations of hydrocarbonoclastic Pseudomonas in the SML (Table 2). Members of this genus have a remarkable ability to degrade a wide range of organic pollutants, including PAHs, halogenated derivates and recalcitrant organic residues (Johnsen et al. 1996, Bhattacharya et al. 2003). Besides their capacity to degrade toxic compounds, species such as $P$. putida can efficiently produce a part of the $\mathrm{OH}$-degrading bacterial groups in estuarine areas exposed to sewage contamination (Rodrigues et al. 2009).

Acinetobacter and Rhizobium were also part of the culturable fraction of PAH degraders in the SML. Many environmental strains of Acinetobacter with hydrocarbon-degrading capacities have been isolated in terrestrial and marine environments (Vanbroekhoven et al. 2004, Rodrigues et al. 2009). Reports of the presence of Rhizobium in PAH-contaminated soils, and its hydrocarbon-degrading metabolism, are also available (Poonthrigpun et al. 2006). One of the isolates was identified as Vibrio, which has also been reported as a $\mathrm{PAH}$ degrader in marine environments (Hedlund \& Staley 2001).

\section{PAH-degrading isolates: detection of dioxygenase genes}

In the present study, an attempt was made to detect genes encoding the enzyme system PAH-RHD $\alpha$ (involved in the initial step in bacterial metabolism of $\mathrm{PAH}$ ) in the bacterioneuston isolates. All isolates, including those having similar BOX-PCR profiles, were screened. Although the isolates were cultivated with 2-methylnaphthalene as the sole source of carbon, and reference to the PAH-degrading capacity was obtained from the literature for all the identified genera (Hedlund \& Staley 2001, Vanbroekhoven et al. 2004, Ma et al. 2006, Poonthrigpun et al. 2006, Rodrigues et al. 2009), PAH-RHD $\alpha$ gene sequences were detected in only 2 of the isolates. A positive 
Table 2. Analysis of the 16S rRNA gene sequences from the isolated strains, and their tentative assignment to different taxonomic categories. GenBank sequence accession numbers of the respective isolate. Number of genotypes clustered in the same BOX group. Blast-N max identity classification. GenBank sequence accession number of most closely related bacterial sequence(s)

\begin{tabular}{|c|c|c|c|c|c|}
\hline $\begin{array}{l}\text { Isolate } \\
\text { code }\end{array}$ & $\begin{array}{c}\text { Sequence } \\
\text { accession no. }\end{array}$ & $\begin{array}{l}\text { BOX } \\
\text { group }\end{array}$ & BLAST-N identity & $\begin{array}{c}\text { Phylogenetic } \\
\text { similarity }\end{array}$ & Accession no \\
\hline 1 & GU935753 & 1 & Serratia sp. & 99 & EF111121.1 \\
\hline 2 & GU935754 & 4 & Uncultured Klebsiella sp. & 95 & EU344923.1 \\
\hline 5 & GU935755 & 2 & Acinetobacter johnsonii & 98 & FJ263917.1 \\
\hline 6 & GU935756 & 1 & Serratia sp. & 97 & EU109729.1 \\
\hline 7 & GU935757 & 1 & Klebsiella sp. & 93 & DQ923489.1 \\
\hline 10 & GU935758 & 1 & Pseudomonas sp. & 96 & FJ424813.1 \\
\hline 12 & GU935759 & 1 & Uncultured Pseudomonas sp. & 96 & EU705005.1 \\
\hline 13 & GU935760 & 1 & Pseudomonas sp. & 98 & FN429930.1 \\
\hline 14 & GU935761 & 1 & Pseudomonas sp. & 97 & AB088548.1 \\
\hline 15 & GU935762 & 1 & Pseudomonas sp. & 94 & DQ839561.1 \\
\hline 16 & GU935763 & 2 & Klebsiella terrigena & 95 & AF129442.1 \\
\hline 19 & GU935764 & 1 & Serratia proteamaculans & 97 & AY559499.1 \\
\hline 20 & GU935765 & 1 & Klebsiella sp. & 97 & EU545402.1 \\
\hline 21 & GU935766 & 1 & Acinetobacter johnsonii & 98 & AM184278.1 \\
\hline 22 & GU935767 & 1 & Rhizobium sp. & 99 & EF599760.1 \\
\hline 23 & GU935768 & 1 & Uncultured Klebsiella sp. & 97 & EU344923.1 \\
\hline 24 & GU935769 & 1 & Pseudomonas sp. & 97 & FJ789687.1 \\
\hline 25 & GU935770 & 1 & Uncultured bacterium & 99 & GQ069755.1 \\
\hline 26 & GU935771 & 1 & Serratia sp. & 96 & EF111121.1 \\
\hline 27 & GU935772 & 1 & Uncultured Pseudomonas sp. & 98 & DQ295987.1 \\
\hline 28 & GU935773 & 3 & Klebsiella sp. & 95 & DQ229100.1 \\
\hline 31 & GU935774 & 2 & Uncultured Klebsiella sp. & 97 & EF679185.1 \\
\hline 32 & GU935775 & 1 & Uncultured Pseudomonas sp. & 95 & DQ295987.1 \\
\hline 36 & GU935776 & 4 & Klebsiella ornithinolytica & 100 & AF129441.1 \\
\hline 37 & GU935777 & 2 & Pseudomonas sp. & 97 & FN429930.1 \\
\hline 40 & GU935778 & 1 & Pseudomonas sp. & 99 & AB506040.1 \\
\hline 41 & GU935779 & 1 & Rhizobium sp. & 98 & EU741078.1 \\
\hline 42 & GU935780 & 2 & Klebsiella sp. & 97 & EU888474.1 \\
\hline 44 & GU935781 & 1 & Vibrio proteolyticus & 93 & DQ995521.1 \\
\hline
\end{tabular}

PCR amplification product was obtained only for isolates \#10 (Pseudomonas spp.) and \#25, an unknown member of the family Enterobacteriaceae. However, the lack of amplification does not exclude the presence of dioxigenases in the other isolates; instead, this result may indicate the presence of novel genes encoding PAH-degrading enzymes in these hydrocarbonoclastic organisms. Moreover, because we did not monitor the complete cleavage of the benzene rings in this study, it cannot be excluded that the isolated strains oxidize only the methyl group of 2-methylnaphtalene. It is possible that the ndo-negative isolates use the methyl group as a source of carbon and energy without cleaving the benzene ring.

Phylogenetic analysis, by BLAST, of our PAH-RHD $\alpha$ gene sequences and their closest relative showed that both PAH-RHD $\alpha$ genes clustered together with the archetypal nahAc gene carried by the plasmid pNAH20 (Yen \& Gunsalus 1982, Heinaru et al. 2000, Sota et al. 2006) (Fig. 2). As identical PAH-RHD $\alpha$ genes with high homology to those in naphthalene-degrading plasmids occur in different bacterial families, it is reasonable to speculate that horizontal gene transfer may also play a role in the occurrence and spreading of hydrocarbonoclastic capacity in the SML. Horizontal exchange of genes encoding the degradation of xenobiotic compounds is a common phenomenon in biofilms (Singh et al. 2006). A preponderance of biofilmgrowing cells in the SML could favour ecological processes that occur in communities with cells in close proximity, such as horizontal gene transfer and quorum sensing (Cunliffe \& Murrell 2009).

\section{The effect of sampling site on the community structure of the bacterioneuston}

$$
\begin{aligned}
& \text { Whole-community and Pseudomonas } \\
& \text { structural diversity }
\end{aligned}
$$

Because most microorganisms are refractory to cultivation, culture-independent methods are fundamental in the characterization of the structure of microbial communities in the environment (Amann et al. 1995).

DGGE was used to assess the structural diversity of the overall bacterial community. The banding pattern 


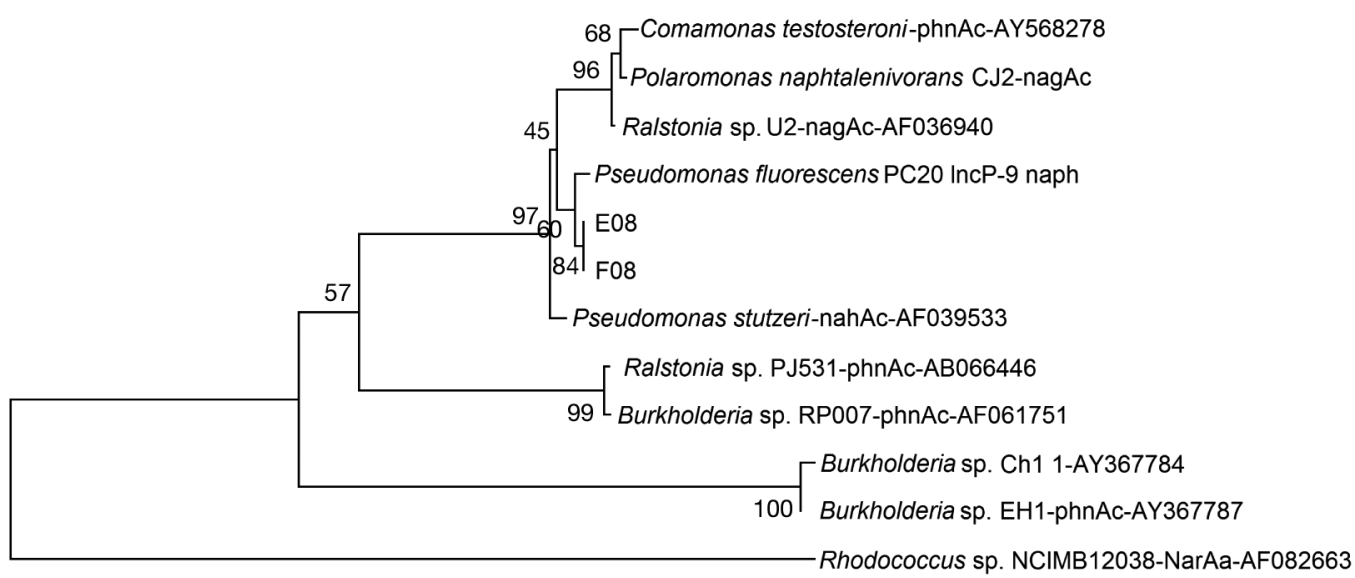

$\longmapsto 0.2$

Fig. 2. Phylogenetic relationships between dioxygenase-encoding genes amplified from the isolated strains (E08 was obtained from Clone 25, F08 from Clone 10). The tree was constructed by using the neighbor-joining method and bootstrapping analysis (1000 repetitions). Numbers on the branches indicate percentages of bootstrap values. Scale bar represents the percentage of amino acid divergence

analysis of the PCR-amplified 16S rRNA gene showed a large number of equally abundant bands in bacterioneuston communities from all the sampling sites (Fig. 3). The Shannon diversity index revealed no significant differences between sites (Table 3). This analysis suggests that the dominant bacterial communities are very similar in the SML of different sampling sites. Earlier studies, using DGGE, found that the dominant bacterioneuston communities were similar in 2 different areas of the Blyth estuary (Cunliffe et al. 2008). Recently, this author also reported that bacterioneuston communities from 2 different areas, close to the Hawaiian Island of Oahu, were more similar to each other than to their subjacent bacterioplankton communities (Cunliffe et al. 2009).

Due to the preponderance of Pseudomonas among the bacteria isolated from the PAH-enrichment culture, and because of the recognized ability of the organisms of this genus to degrade PAHs, we paid particular attention to the diversity of a Pseudomonas genetic marker in the SML at all sites. The Pseudomonas-specific gacA gene was used as a genetic marker for this genus. This gene influences the production of several secondary metabolites in Pseudomonas sp., and it can be used as a complementary genetic marker for detecting bacteria of this genus in environmental samples (De Souza et al. 2003).

Interestingly, contrary to what was observed for the bacterial fingerprints, analysis of the Pseudomonas community showed a significant $\left(\mathrm{p}_{\text {ANOVA }}<0.05\right)$ increase in diversity (Table 3 ) from the outer (Stn S1) to the middle (Stn S3) and inner (Stn S5) sections of the

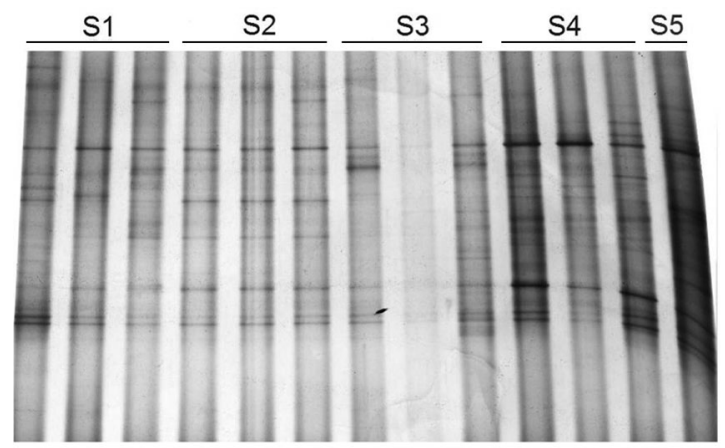

Fig. 3. Denaturing-gradient gel electrophoresis fingerprints of 16S rRNA gene fragments amplified from bacterioneuston obtained from the surface microlayer at Stns S1, S2, S3, S4 and S5

estuary, following the concentrations of $\mathrm{PAH}$ and organic matter. This pattern may explain the high abundance of Pseudomonas strains recovered from the SML-PAH enrichments obtained in the area with higher levels of lighter (low-molecular-weight) PAHs. As previously mentioned, members of this genus are known for their ability to metabolize light PAH compounds and other monoaromatic hydrocarbons.

The gacA DGGE pattern of the isolated strains, and the gacA profile of whole bacterioneuston, show a common band with the mobility exhibited by isolate \#27 (Fig. 4). This band is present in the bacterioneuston from Stns S1, S2 and S3, but is absent in samples from Stns S4 and S5, at the inner section of the estuary. Interestingly, isolate \#27 showed a high 
Table 3. Mean \pm SD of the Shannon diversity indices calculated from denaturing-gradient gel electrophoresis (DGGE) profiles of bacterial 16S rRNA and the Pseudomonas-specific gacA gene in bacterioneuston from the surface microlayer at Stns S1, S2, S3, S4 and S5

\begin{tabular}{|c|c|c|c|c|c|}
\hline \multirow{2}{*}{ DGGE profile } & \multicolumn{5}{|c|}{ - Shannon diversity indices at Stn- } \\
\hline & S1 & S2 & S3 & S4 & S5 \\
\hline Pseudomonas-specific gacA & $0.9 \pm 0.2$ & $1.3 \pm 0.5$ & $2.0 \pm 0.2$ & $2.0 \pm 0.2$ & $2.2 \pm 0.2$ \\
\hline Bacterial 16S rRNA & $2.36 \pm 0.29$ & $2.24 \pm 0.24$ & $2.44 \pm 0.29$ & $2.22 \pm 0.37$ & $2.58^{\mathrm{a}}$ \\
\hline
\end{tabular}

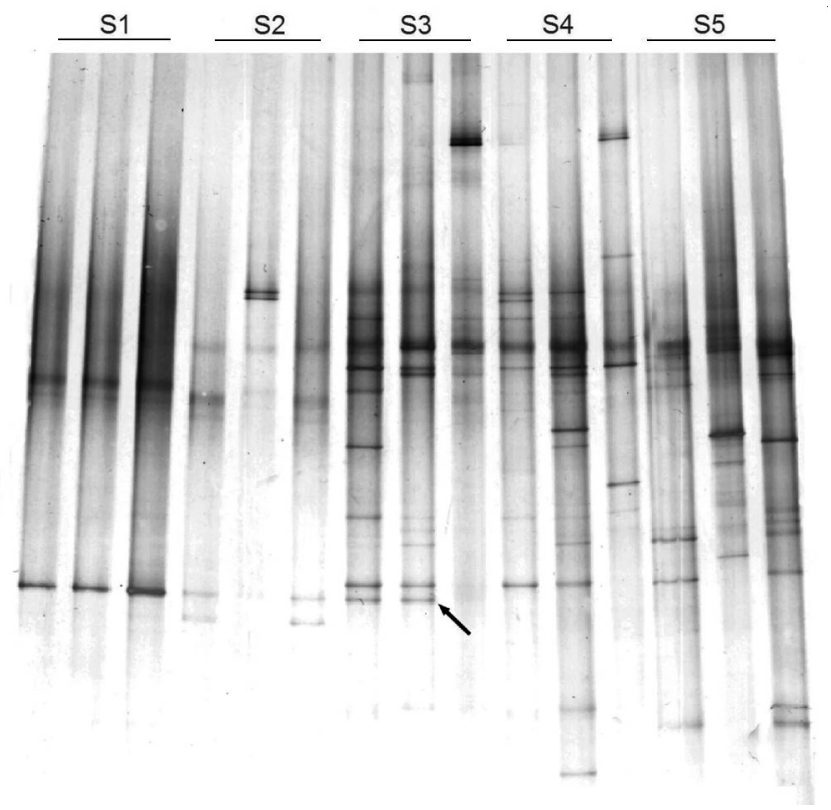

Fig. 4. Denaturing-gradient gel electrophoresis (DGGE) fingerprints of Pseudomonas-specific gacA gene fragments amplified from bacterioneuston in the surface microlayer collected at Stns S1, S2, S3, S4 and S5. The position of the arrow corresponds to the melting behaviour of isolate \#27, classified as an uncultured Pseudomonas sp.

homology with an uncultured Pseudomonas which has been linked to the transformation of organic compounds in coastal seawater (Mou et al. 2007). These results suggest that the distribution of Pseudomonas populations may also be related to the quality and composition of lipophilic organic compounds in the SML.

\section{Microbial abundance overall and in the Gammaproteobacteria}

FISH was applied in this study to assess the spatial variability in the total abundance of microorganisms and also for quantifying members of the domain Bacteria and the Gammaproteobacteria in the SML (Amann et al. 1990, Manz et al. 1992, Karner \& Fuhrman 1997, Daims et al. 1999, Pernthaler et al. 2001).

The overall abundance of microorganisms estimated from DAPI counts ranged from $2.3 \pm 0.2 \times 10^{6} \mathrm{cells} \mathrm{ml}^{-1}$ at Stn S1, to $5.0 \pm 0.9 \times 10^{6}$ cells ml $^{-1}$ at Stn S5, defining a significant $\left(\mathrm{p}_{\text {ANOVA }}<0.05\right)$ gradient of enrichment from the outer to the inner sections of the estuary (Fig. 5). The total cell number is within the range $(4.9 \times$ $10^{5}$ cells ml ${ }^{-1}$ to $6.2 \times 10^{6}$ cells ml $^{-1}$ ) observed in the Ria de Vigo estuary (Zdanowski \& Figueiras 1997). The pattern of variation that we detected corresponds, in general, to the structure of an estuary in which bacterial abundance and phytoplankton biomass are maximal at the intermediate sections (Wright \& Coffin 1983, Fuks et al. 1991, Cunha et al. 2003). This distribution is probably related to the quality (lability) of the available organic matter along the estuary.

The relative abundance of organisms of the domain Bacteria varied between $50.4 \pm 3.6 \%$ at Stn S2 and $66.7 \pm 9.2 \%$ at Stn S4 (Fig. 5). The proportion of cells hybridized by the Bacteria probes is within the $60 \%$ average reported for the Delaware estuary (Kirchman et al. 2005). The missing percentage could be related to other groups not covered by this study. By applying CARD-FISH, one study found that up to $37 \%$ of the total cell numbers recovered from the SML in high mountain lakes hybridized with Archaea-specific probes (Auguet \& Casamayor 2008). The relative abundance of organisms of the domain Bacteria did not show a defined trend of spatial variation along the estuary.

On the contrary, the highest value for the relative abundance of organisms of the Gammaproteobacteria $(19.7 \pm 1.0 \%)$ was found in the SML at Stn S3 (Fig. 5), where naphthalene and phenantrene were detected. Gammaproteobacteria were selected as a target for FISH analysis because this group includes many of the PAH-degrading genera, such as Alcanivorax, Cycloclasticus, Pseudomonas, Oleiphilus, Oleispira and Thalassolituus (Watanabe 2001, Head et al. 2006). Although the abundance and distribution of microorganisms in marine and estuarine waters is influenced by complex biotic and abiotic interactions 


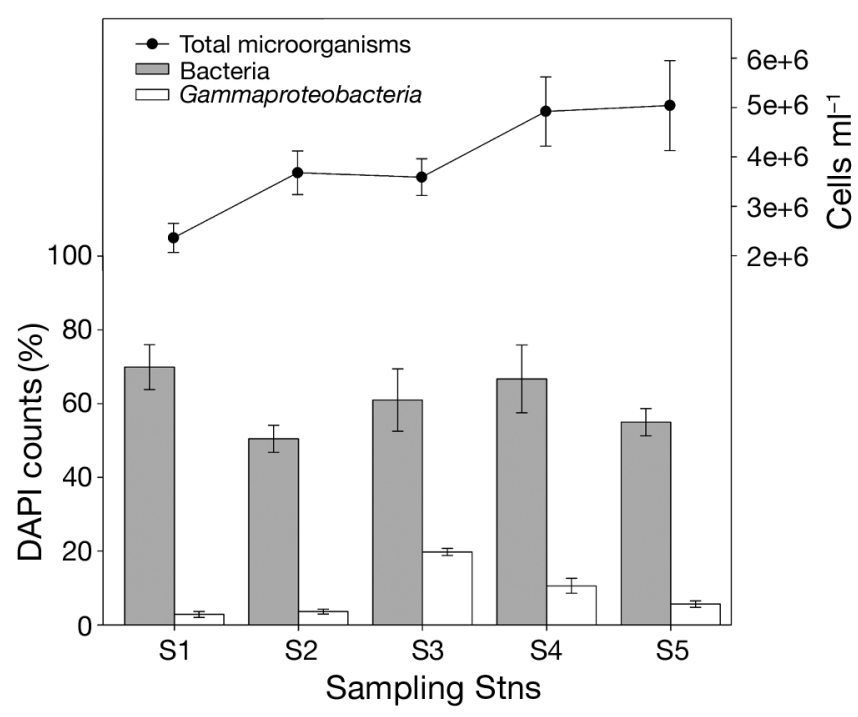

Fig. 5. Variations in total prokaryote abundance (as counted by 4 ,6-diamidino-2-phenylindole [DAPI] staining) and relative abundance of Bacteria and Gammproteobacteria (\% of DAPI counts) determined by fluorescence in situ hybridization in bacterioneuston in the surface microlayer collected at Stns S1, S2, S3, S4 and S5. (In the scale: $2 \mathrm{e}+6=2 \times 10^{6}$ etc.)

(Shiah \& Ducklow 1995), the high concentration of low-molecular-weight PAHs, generally easily degraded (Yamada et al. 2003), at sampling Stn S3 can be related to the high relative abundance of Gammaproteobacteria at this site. Exposure to hydrocarbons has been shown to decrease bacterial diversity, as a result of selection in favour of PAH-degrading bacteria (Röling et al. 2002, Castle et al. 2006). Nonetheless, other sources of organic carbon might also have influenced the distribution of this group. The preference of Gammaproteobacteria for high concentrations of nutrients has been previously reported, and peaks of abundance appeared to be related to particular point sources of nutrients (Bouvier \& del Giorgio 2002, Henriques et al. 2004).

\section{CONCLUSIONS}

To our knowledge, we are the first to isolate and characterize hydrocarbonoclastic strains of bacterioneuston from estuarine SML exposed to chronic $\mathrm{OH}$ contamination; the most dominant isolates belonged to the genus Pseudomonas (members of the Gammaproteobacteria).

The SML is the first marine habitat to be in contact with hydrophobic $\mathrm{OH}$ pollutants after an oil spill accident. The possibility of using hydrocarbonoclastic bacterioneuston isolates in a bioremediation strategy for the rapid degradation of oil slicks should be examined in future studies. The SML has the potential to be a natural 'seed bank' that can be useful for isolating and 'domesticating' novel bacteria for PAH degradation. The ability of the hydrocarbonoclastic bacterioneuston to withstand and degrade toxic compounds, together with its capacity to survive in this environment, make the isolates recovered in this study interesting candidates for future research on in situ SML bioremediation.

The cultivation-independent analyses (FISH counts and Pseudomonas-DGGE) agreed with the isolation results. These findings indicate that the abundance of Gammaproteobacteria and the diversity of Pseudomonas in the bacterioneuston have undergone significant changes in areas contaminated with elevated levels of $\mathrm{OH}$ in the Ria de Aveiro. However, the ecological role of the bacterioneuston in the degradation of hydrophobic $\mathrm{OH}$ pollutants is still unclear. Future work should focus on more in-depth functional analyses of genes whose expression/repression are most likely related to SML contamination by $\mathrm{OH}$ compounds.

Acknowledgements. The authors thank the 2 anonymous reviewers for their constructive and critical comments that considerably improved the earlier versions of the manuscript. This work was supported by the Center for Environmental and Marine Studies (CESAM) and the Foundation for Science and Technology (FCT, Portugal) PTDC/AAC-CLI/107916/2008 (http://alfa.fct.mctes.pt/). Financial support to F.J.R.C.C., L.S. and A.L.S. was provided by FCT in the form of $\mathrm{PhD}$ grants SFRH/BD/46322/2008, SFRH/BD/31827/2006 and SFR/BD/ 40160/2007.

\section{LITERATURE CITED}

Amann RI, Krumholz L, Stahl DA (1990) Fluorescent-oligonucleotide probing of whole cells for determinative, phylogenetic, and environmental studies in microbiology. J Bacteriol 172:762-770

Amann RI, Ludwig W, Schleifer KH (1995) Phylogenetic identification and in situ detection of individual microbial cells without cultivation. Microbiol Rev 59:143-169

> Auguet JC, Casamayor EO (2008) A hotspot for cold Crenarchaeota in the neuston of high mountain lakes. Environ Microbiol 10:1080-1086

Bhattacharya D, Sarma PM, Krishnan S, Mishra S, Lal B (2003) Evaluation of genetic diversity among Pseudomonas citronellolis strains isolated from oily sludge-contaminated sites. Appl Environ Microbiol 69:1435-1441

Bouvier TC, del Giorgio PA (2002) Compositional changes in free-living bacterial communities along a salinity gradient in two temperate estuaries. Limnol Oceanogr 47:453-470

Castle DM, Montgomery MT, Kirchman DL (2006) Effects of naphthalene on microbial community composition in the Delaware estuary. FEMS Microbiol Ecol 56:55-63

Cébron A, Norini MP, Beguiristain T, Leyval C (2008) Realtime PCR quantification of PAH-ring hydroxylating dioxygenase (PAH-RHD $\alpha$ ) genes from Gram-positive and Gram-negative bacteria in soil and sediment samples. J Microbiol Methods 73:148-159 
Cincinelli A, Stortini AM, Perugini M, Checchini L, Lepri L (2001) Organic pollutants in sea-surface microlayer and aerosol in the coastal environment of Leghorn-(Tyrrhenian Sea). Mar Chem 76:77-98

Costa R, Salles JF, Berg G, Smalla K (2006) Cultivation-independent analysis of Pseudomonas species in soil and in the rhizosphere of field-grown Verticillium dahliae host plants. Environ Microbiol 8:2136-2149

Costa R, Gomes NCM, Krogerrecklenfort E, Opelt K, Berg G, Smalla K (2007) Pseudomonas community structure and antagonistic potential in the rhizosphere: insights gained by combining phylogenetic and functional gene-based analyses. Environ Microbiol 9:2260-2273

> Cunha MA, Almeida MA, Alcãntara F (2000) Patterns of ectoenzymatic and heterotrophic bacterial activities along a salinity gradient in a shallow tidal estuary. Mar Ecol Prog Ser 204:1-12

Cunha MA, Almeida MA, Alcântara F (2003) Ectoenzymatic activity and glucose heterotrophic metabolism in a shallow estuary (Ria de Aveiro, Portugal): influence of bed sediments and salt marshes. Acta Oecol 24:S97-S107

Cunliffe M, Schafer H, Harrison E, Cleave S, Upstill-Goddard R, Murrell JC (2008) Phylogenetic and functional gene analysis of the bacterial and archaeal communities associated with the surface microlayer of an estuary. ISME J 2: 776-789

Cunliffe M, Murrell JC (2009) The sea-surface microlayer is a gelatinous biofilm. ISME J 3:1001-1003

Cunliffe M, Harrison E, Salter M, Schäfer H, Upstill-Goddard RC, Murrell JC (2009) Comparison and validation of sampling strategies for the molecular microbial analysis of surface microlayers. Aquat Microb Ecol 57:69-77

Cunliffe M, Upstill-Goddard RC, Murrell JC (2011) Microbiology of aquatic surface microlayers. FEMS Microbiol Rev 35:233-246

Daims H, Bruhl A, Amann R, Schleifer KH, Wagner M (1999) The domain-specific probe EUB338 is insufficient for the detection of all Bacteria: development and evaluation of a more comprehensive probe set. Syst Appl Microbiol 22: 434-444

> De Souza JT, Mazzola M, Raaijmakers JM (2003) Conservation of the response regulator gene gacA in Pseudomonas species. Environ Microbiol 5:1328-1340

Franklin MP, McDonald IR (2005) Bacterial diversity in the bacterioneuston (sea surface microlayer): the bacterioneuston through the looking glass. Environ Microbiol 7(5):723-736

Fuks D, Devescovi M, Precali R, Krstulovic N, Solic M (1991) Bacterial abundance and activity in the highly stratified estuary of the Krka River. Mar Chem 32:333-346

Hardy JT (1982) The sea surface microlayer: biology, chemistry and anthropogenic enrichment. Prog Oceanogr 11: 307-328

> Harvey GW, Burzell LA (1972) A simple microlayer method for small samples. Limnol Oceanogr 17:156-157

Head IM, Jones DM, Röling WFM (2006) Marine microorganisms make a meal of oil. Nat Rev Microbiol 4:173-182

Hedlund BP, Staley JT (2001) Vibrio cyclotrophicus sp. nov., a polycyclic aromatic hydrocarbon (PAH)-degrading marine bacterium. Int J Syst Evol Microbiol 51:61-66

Heinaru E, Truu J, Stottmeister U, Heinaru A (2000) Three types of phenol and $p$-cresol catabolism in phenol- and $p$ cresol-degrading bacteria isolated from river water continuously polluted with phenolic compounds. FEMS Microbiol Ecol 31:195-205

> Henriques IS, Almeida A, Cunha A, Correia A (2004) Molecular sequence analysis of prokaryotic diversity in the mid- dle and outer sections of the Portuguese estuary Ria de Aveiro. FEMS Microbiol Ecol 49:269-279

Heuer $\mathrm{H}$, Wieland J, Schönfeld J, Schönwälder A, Gomes NCM, Smalla K (2001) Bacterial community profiling using DGGE or TGGE analysis. In: Rouchelle P (ed) Environmental molecular microbiology: protocols and applications. Horizon Scientific Press, Wymondham, p 177-190

Johnsen K, Andersen S, Jacobsen CS (1996) Phenotypic and genotypic characterization of phenanthrene-degrading fluorescent Pseudomonas biovars. Appl Environ Microbiol 62:3818-3825

Karner M, Fuhrman JA (1997) Determination of active marine bacterioplankton: a comparison of universal 16S rRNA probes, autoradiography, and nucleoid staining. Appl Environ Microbiol 63:1208-1213

Kasai Y, Kishira H, Harayama S (2002) Bacteria belonging to the genus Cycloclasticus play a primary role in the degradation of aromatic hydrocarbons released in a marine environment. Appl Environ Microbiol 68:5625-5633

> Kirchman DL, Dittel AI, Malmstrom RR, Cottrell MT (2005) Biogeography of major bacterial groups in the Delaware Estuary. Limnol Oceanogr 50:1697-1706

Liss PS, Duce RA (1997) The sea surface and global change. Cambridge University Press, Cambridge, UK

> Ma Y, Wang L, Shao Z (2006) Pseudomonas, the dominant polycyclic aromatic hydrocarbon-degrading bacteria isolated from Antarctic soils and the role of large plasmids in horizontal gene transfer. Environ Microbiol 8:455-465

Manz W, Amann R, Ludwig W, Wagner M, Schleifer KH (1992) Phylogenetic oligodeoxynucleotide probes for the major subclasses of proteobacteria: problems and solutions. Syst Appl Microbiol 15:593-600

Mou X, Hodson RE, Moran MA (2007) Bacterioplankton assemblages transforming dissolved organic compounds in coastal seawater. Environ Microbiol 9:2025-2037

Nubel U, Engelen B, Felske A, Snaidr J and others (1996) Sequence heterogeneities of genes encoding 16S rRNAs in Paenibacillus polymyxa detected by temperature gradient gel electrophoresis. J Bacteriol 178:5636-5643

> Obernosterer I, Catala P, Reinthaler T, Herndl GJ, Lebaron P (2005) Enhanced heterotrophic activity in the surface microlayer of the Mediterranean Sea. Aquat Microb Ecol 39:293-302

Pernthaler J, Glöckner FO, Schönhuber W, Amann R (2001) Fluorescence in situ hybridization (FISH) with rRNAtargeted oligonucleotide probes. Meth Microbiol 30: $207-226$

> Poonthrigpun S, Pattaragulwanit K, Paengthai S, Kriangkripipat $T$ and others (2006) Novel intermediates of acenaphthylene degradation by Rhizobium sp. strain CU-A1: evidence for naphthalene-1,8-dicarboxylic acid metabolism. Appl Environ Microbiol 72:6034-6039

Puchałka J, Oberhardt MA, Godinho M, Bielecka A and others (2008) Genome-scale reconstruction and analysis of the Pseudomonas putida KT2440 metabolic network facilitates applications in biotechnology. PLoS Comput Biol 4: e1000210 doi:10.1371/journal.pcbi.1000210

Rademaker JLW, Louws FJ, Versalovic J Bruijn FJd (1998) Characterization of the diversity of ecologically important microbes by rep-PCR genomic fingerprinting. In: Kowalchuk GA, Bruijn FJd, Head IM, Akkermans ADL, Elsas JDv (eds) Molecular microbial ecology manual, Supplement. Kluwer Academic Publishers, Dordrecht, p 1-26

> Rodrigues DF, Sakata SK, Comasseto JV, Bícego MC, Pellizari VH (2009) Diversity of hydrocarbon-degrading Klebsiella strains isolated from hydrocarbon-contaminated estuaries. J Appl Microbiol 106:1304-1314 
Röling WFM, Milner MG, Jones DM, Lee K, Daniel F, Swannell RJP, Head IM (2002) Robust hydrocarbon degradation and dynamics of bacterial communities during nutrientenhanced oil spill bioremediation. Appl Environ Microbiol 68:5537-5548

Shiah FK, Ducklow HW (1995) Multiscale variability in bacterioplankton abundance, production, and specific growth rate in a temperate salt-marsh tidal creek. Limnol Oceanogr 40:55-56

Sieburth JM (1983) Microbiological and organic-chemical processes in the surface and mixed layers. In: Liss PS, Slinn WGN (eds) Air-sea exchange of gases and particles. Reidel, Hingham, MA, p 121-172

Singh R, Paul D, Jain RK (2006) Biofilms: implications in bioremediation. Trends Microbiol 14:389-397

Sota M, Yano H, Ono A, Miyazaki R and others (2006) Genomic and functional analysis of the IncP-9 naphthalene-catabolic plasmid NAH7 and its transposon Tn4655 suggests catabolic gene spread by a tyrosine recombinase. J Bacteriol 188:4057-4067

Sporstol S, Gjos N, Lichtenthaler RG, Gustavsen KO, Urdal K, Oreld F, Skei J (1983) Source identification of aromatic hydrocarbons in sediments using GC/MS. Environ Sci Technol 17:282-286

> Vanbroekhoven K, Ryngaert A, Wattiau P, De Mot R, Springael D (2004) Acinetobacter diversity in environmental samples assessed by 16S rRNA gene PCR-DGGE fingerprinting. FEMS Microbiol Ecol 50:37-50

Editorial responsibility: Gerhard Herndl, Vienna, Austria
Wackett LP (2003) Pseudomonas putida-a versatile biocatalyst. Nat Biotechnol 21:136-138

- Watanabe K (2001) Microorganisms relevant to bioremediation. Curr Opin Biotechnol 12:237-241

> Weisburg WG, Barns SM, Pelletier DA, Lane DJ (1991) 16S ribosomal DNA amplification for phylogenetic study. J Bacteriol 173:697-703

Wright R, Coffin R (1983) Planktonic bacteria in estuaries and coastal waters of northern Massachusetts: spatial and temporal distribution. Mar Ecol Prog Ser 11: 205-216

Wurl O, Holmes M (2008) The gelatinous nature of the seasurface microlayer. Mar Chem 110:89-97

Wurl O, Obbard JP (2004) A review of pollutants in the seasurface microlayer (SML): a unique habitat for marine organisms. Mar Pollut Bull 48:1016-1030

Yamada M, Takada H, Toyoda K, Yoshida A and others (2003) Study on the fate of petroleum-derived polycyclic aromatic hydrocarbons (PAHs) and the effect of chemical dispersant using an enclosed ecosystem, mesocosm. Mar Pollut Bull 47:105-113

> Yen KM, Gunsalus IC (1982) Plasmid gene organization: naphthalene/salicylate oxidation. Proc Natl Acad Sci USA 79:874-878

Zdanowski MK, Figueiras FG (1997) Relationships between the abundance of bacteria and other biota and the hydrographic variability in the Ría de Vigo, Spain. Mar Ecol Prog Ser 147:257-267

Submitted: January 17, 2011; Accepted: June 9, 2011

Proofs received from author(s): August 13, 2011 